\title{
PIPAC may work but more data is needed
}

\author{
Paul H. Sugarbaker ${ }^{1}$, Kurt Van der Speeten ${ }^{2}$ \\ ${ }^{1}$ MedStar Washington Hospital Center, Washington, DC, USA; ${ }^{2}$ Department of Surgery, Hospital Oost-Limburg, Genk, Belgium \\ Correspondence to: Paul H. Sugarbaker, MD. MedStar Washington Hospital Center, Washington, DC, USA. Email: Paul.Sugarbaker@outlook.com; \\ Kurt Van der Speeten. Department of Surgery, Hospital Oost-Limburg, Genk, Belgium. Email: Kurt.Vanderspeeten@zol.be. \\ Comment on: Lurvink RJ, Rovers KP, Nienhuijs SW, et al. Pressurized intraperitoneal aerosol chemotherapy with oxaliplatin (PIPACOX) in patients \\ with colorectal peritoneal metastases—a systematic review. J Gastrointest Oncol 2021;12:S242-58. \\ Lurvink RJ, Van der Speeten K, Rovers KP, et al. The emergence of pressurized intraperitoneal aerosol chemotherapy as a palliative treatment option \\ for patients with diffuse peritoneal metastases: a narrative review. J Gastrointest Oncol 2021;12:S259-70.
}

Submitted Dec 16, 2020. Accepted for publication Mar 16, 2021.

doi: 10.21037/jgo-2020-22

View this article at: http://dx.doi.org/10.21037/jgo-2020-22

Lurvink and coworkers establish that PIPAC has emerged as a palliative treatment option for several gastrointestinal diseases $(1,2)$. The pharmacologic data are favorable and available retrospective studies and registry data demonstrate promising results. However, it is an expensive treatment in that an invasive surgical procedure, laparoscopy, must accompany each cycle of PIPAC. The cycles are repeated every 3-4 weeks as tolerated by the patient. PIPAC has gained considerable momentum in Europe but is not as yet approved as a surgical technology for use in the United States. It seems it should be compared to repeated cycles of laparoscopic HIPEC (nonpressurized and non-aerosolized). Also, it should be compared in a trial to long-term NIPEC given by an intraperitoneal port. Of course, it needs to be compared to long-term systemic chemotherapy or systemic chemotherapy plus biologic therapy.

Several phase-III trials to that extent are currently recruiting. At this point in time, it should be considered an experimental treatment; to be performed within the scope of trial or registry in an experienced center.

\section{Acknowledgments}

Funding: None.

\section{Footnote}

Provenance and Peer Review: This article was commissioned by the editorial office, Fournal of Gastrointestinal Oncology for the focused issue "Intraperitoneal Chemotherapy for Peritoneal Metastases: HIPEC, EPIC, NIPEC, PIPAC and
More". The article did not undergo external peer review.

Conflicts of Interest: Both authors have completed the ICMJE uniform disclosure form (available at http://dx.doi.org/10.21037/ jgo-2020-22). The focused issue was sponsored by the Peritoneal Surface Oncology Group International (PSOGI). Drs. PHS and KVDS served as the unpaid Guest Editors of the focused issue. The authors have no other conflicts of interest to declare.

Ethical Statement: The authors are accountable for all aspects of the work in ensuring that questions related to the accuracy or integrity of any part of the work are appropriately investigated and resolved.

Open Access Statement: This is an Open Access article distributed in accordance with the Creative Commons Attribution-NonCommercial-NoDerivs 4.0 International License (CC BY-NC-ND 4.0), which permits the noncommercial replication and distribution of the article with the strict proviso that no changes or edits are made and the original work is properly cited (including links to both the formal publication through the relevant DOI and the license). See: https://creativecommons.org/licenses/by-nc-nd/4.0/.

\section{References}

1. Lurvink RJ, Rovers KP, Nienhuijs SW, et al. Pressurized intraperitoneal aerosol chemotherapy with oxaliplatin (PIPACOX) in patients with colorectal peritoneal metastases—a systematic review. J Gastrointest Oncol 
2021;12:S242-58.

2. Lurvink RJ, Van der Speeten K, Rovers KP, et al. The emergence of pressurized intraperitoneal aerosol chemotherapy as a palliative treatment option for patients with diffuse peritoneal metastases: a narrative review. $\mathrm{J}$ Gastrointest Oncol 2021;12:S259-70.

Cite this article as: Sugarbaker PH, Van der Speeten K. PIPAC may work but more data is needed. J Gastrointest Oncol 2021;12(Suppl 1):S271-S272. doi: 10.21037/jgo-2020-22 